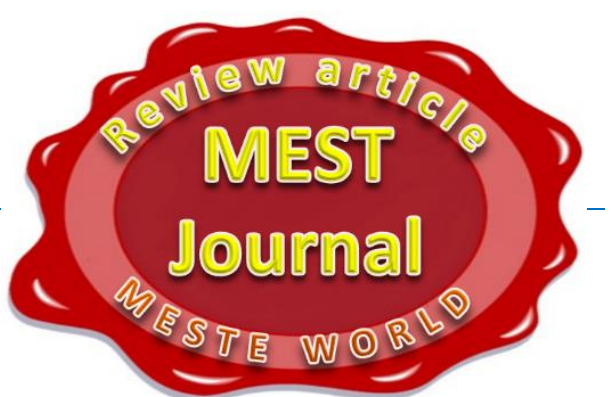

\title{
NATURAL LAW AND SOCIAL CONTRACT: CONSERVATIVE PHILOSOPHERS' VIEW (XVII - XVIII CENTURIES)
}

\section{Yurii S. Kononenko}

Bohdan Khmelnytsky National University of Cherkasy, Cherkasy, Ukraine https://orcid.org/0000-0003-3703-7774

\section{Sergii V. Dzholos}

Bohdan Khmelnytsky National University of Cherkasy, Cherkasy, Ukraine https://orcid.org/0000-0002-0001-5523

OMESTE

JEL Category: I30, K10, K38

\begin{abstract}
The article is devoted to the clarification of the essence of the conservative versions of the natural law and social contract theories, presented in the works of famous English and German philosophers of the XVII - XVIII centuries, such as T. Hobbes, E. Burke, S. Pufendorf, G.W. Leibniz, Ch. Thomasius, $\mathrm{Ch}$. Wolff and others. The methodology of the research includes dialectic, metaphysics, hermeneutics, teleological, genetical, logical, comparative, historical, and legal methods. The authors say that the theory of natural law and social contract is not only the doctrine but also the approach to the understanding of the political and legal phenomena, which allows justifying the liberal and the conservative view on the state and law. The philosophers of the conservative worldview substantiated that people had handed over their freedom to the state by the social contract. So, the state should have supreme and unlimited power over its citizens, who lost the right of rebellion, but the state aims to ensure the welfare of people. So, the theory of the social contract and natural law may be used to justify the ideas of etatism, paternalism, monarchy, the police state, serfdom, and limitation of human rights, as well as the violent nature of any governance. The authors substantiated, that the theory of the social contract remains relevant to this day, and it may be organically combined with the patriarchal and classmaterialist theory of the origin of the state, as well as with the theory of violence.
\end{abstract}

Keywords: state, law, natural law, social contract, conservatism, liberalism, rebellion, power, violence, welfare.

\section{INTRODUCTION}

The theories of the natural law and the social contract were especially popular in the XVII - XVIII

Address of the corresponding author:

Sergii V. Dzholos

表”debofor@gmail.com centuries. It is considered that these theories became the fountainhead of democracy, human rights, rule of law, constitutional and law-bound state, civil society, and other ideas of the liberal 
political and legal ideology of the Western civilization. At the same time, each philosopher of that great and glorious epoch created his original doctrine, and its main conclusions may differ significantly from the ideas of other thinkers of that period.

It is necessary to say that ideas of natural law and social contract have many supporters among philosophers, including Mozi (Demydenko, Petryshyn, 2009, p. 18), Socrates, Plato, Aristotle (Bobrovnyk, 2003), Epicurus, Hugo Grotius, Thomas Hobbes, Baruch Spinoza, John Locke, Jean-Jacques Rousseau (Romanyuk, 2003), Alexander Nikolayevich Radishchev, John Milton, John Lilburne, Algernon Sidney, Samuel Freiherr von Pufendorf, Christian Thomasius, Christian Freiherr von Wolff (Tymoshenko, 1998) and others. It should be noted that time and geographical boundaries, or, more precisely, the boundlessness of the popularity of these ideas show us that natural law and social contract are much wider than just ordinary political and legal theories, and are a kind of meta-concepts or, rather, approaches to understanding and interpreting the essence of state and legal phenomena. So, it is not surprising that the approach, based on the ideas of natural law and social contract, allows thinkers to do a variety of opposed conclusions on the state and law.

So, this article aims to show the peculiarities of the political and legal doctrines and to pay our respect to great English and German philosophers of the XVII - XVIII centuries, such as Thomas Hobbes (1588-1679), Edmund Burke (1729-1797), Samuel Freiherr von Pufendorf (1632-1694), Gottfried Wilhelm (von) Leibniz (1646-1716), Christian Thomasius (1655-1728), Christian Freiherr von Wolff (1679-1754), who created their original conservative approaches to the natural law and social contract theories, which are actually by the present time and help to understand better the essence of state and law.

\section{THE "MAINSTREAM" IDEAS OF THE NATURAL LAW AND SOCIAL CONTRACT THEORIES}

In general, the heyday of the theory of natural law and social contract dates back to the XVII - XVIII centuries due to the crisis of the religious worldview in the Renaissance and Reformation, the transition from feudalism to capitalism, the significant progress of the natural sciences and secular philosophy in this period.

Pavel Ivanovich Novgorodtsev says that the English school of natural law was closer to the practical events of the time, to the political struggle in which English political freedom was strengthened. As a result, English theories became much more radical (Novgorodtsev, 1898, p. 887), which is not surprising, if we remember many internal upheavals experienced by England in the XVII century, including such as the transition of power from Tudors to Stewarts (1603), the Gunpowder Plot (1605), the English Revolution and Civil War (1640-1649), the dictatorship of Oliver Cromwell (1649-1658), the Plot of the general George Monck and the Restoration of the Stuart monarchy (1660), the Monmouth Rebellion (1685), the Glorious Revolution (1688), etc.

Taking into consideration the piety of Voltaire and other French philosophers of the Age of Enlightenment to the English political system (Demydenko, Petryshyn, 2009, p. 99-100), as well as the British colonial expansion, the American neocolonialism of the Age of Globalization and the expansion of the Western civilization, it is not surprising that now the most popular versions of the theory of natural law and social contract are the teachings of the founder of liberalism John Locke (1632-1704) and the founder of political radicalism Jean-Jacques Rousseau (1712-1778).

On the grounds of the natural law and social contract, Jean-Jacques Rousseau developed the theory of popular sovereignty, which says that the just social contract should be concluded between the equal parties, but not between the ruler and serfs. Such contract should be based on the principle of popular sovereignty or the common will, which can rule by the strength of the state, according to the aim of its creation, which is the common welfare (Rousseau, 1762). The people create laws but are not bound by them for all time, and even the social contract is not obligatory to the people. The people have the right to change the form of government and even to terminate the social contract and to take back the natural freedom, so people have the right to rebellion against tyranny (Demydenko, Petryshyn, 2009, p. 104). At the same time, John Locke says that people, as the equal party of the social contract, 
have the natural right to terminate it at any moment, especially if the authority breaks the laws and governs ineffectively or tyrannically (Locke, 1690).

3 THE CONSERVATIVE VIEW OF THE ENGLISH AND GERMAN PHILOSOPHERS OF THE XVII XVIII CENTURIES ON THE ESSENCE OF STATE AND LAW, BASED ON THE THEORY OF NATURAL LAW AND SOCIAL CONTRACT

At the same time, it is necessary to say that many philosophers, especially German and English, had other understanding of the natural law and social contract. Thomas Hobbes (1588-1679) says that in the pre-state "natural conditions", due to unbridled human passions and selfishness, the "war of all against all" prevailed. To overcome it, the people concluded a social contract and renounced their boundless natural freedom (including the right to rebellion) in favor of the state. And the last one has the aim to ensure peace, order, and prosperity, and, like the mighty sea monster Leviathan, should have unlimited power over its subjects (Hobbes, 1651; Kukhta, 2003).

Edmund Burke (1729-1797) writes: "Society is indeed a contract. Subordinate contracts for objects of mere occasional interest may be dissolved at pleasure - but the state ought not to be considered as nothing better than a partnership agreement in a trade of pepper and coffee, calico, or tobacco, or some other such low concern, to be taken up for a little temporary interest, and to be dissolved by the fancy of the parties. It is to be looked on with other reverence because it is not a partnership in things subservient only to the gross animal existence of a temporary and perishable nature. It is a partnership in all science; a partnership in all art; a partnership in every virtue and all perfection. As the ends of such a partnership cannot be obtained in many generations, it becomes a partnership not only between those who are living, but between those who are living, those who are dead, and those who are to be born" (Burke, 1790).

So, Edmund Burke teaches that the social contract is the fundamental base of statehood, and it aims to ensure political and economic stability as the guarantee of social development. At the same time, the philosopher says that the social contract should ensure the aristocratic rule: the creation of the state with the help of the social contract has the aim to guarantee the necessities of a human and to do it, it is necessary to limit human passions, and it may be done only by the authority, which does not have these passions, so this authority should be higher than a human (Burke, 1790).

...At the same time, the Holy Roman Empire of the German nation underwent significant upheavals during the Reformation of the XVI century and the Thirty Years' War of 1618-1648, so, naturally, German philosophers of the XVII - XVIII centuries sought to justify with the help of the natural law and social contract, not the right to rebellion (which would drive the last nail in the coffin of German statehood), but rather a strong state and absolutism, which would ensure order and prosperity. So, it is necessary to talk about the ideas of the German philosophers of that period in more detail.

Samuel Freiherr von Pufendorf (1632-1694) was the first German philosopher, who started to create secular juridical science. He believed that the law should be consistent with the laws of reason, regardless of religious dogmas and current legislation. According to the thinker, the increase in population has caused people to fear the possible harm that can be caused by human selfishness, so people create a state that would ensure mutual benefit and security. The state is formed as a result of a social contract consisting of two agreements. The first one is an agreement among people to unite and choose the form of government. The second one is an agreement between the people and their elected rulers, which prescribes people to obey their ruler, and to the ruler to take care of the people to ensure their safety and common welfare. At the same time, the best form of government is an unlimited monarchy, because it is the most suitable for ensuring public order and security of subjects. People lost their natural freedom during the formation of the state, which received the right to punish them in the name of the common good. A peculiar consequence of state formation and social contract is not only princely absolutism but also serfdom, which is a voluntary agreement between 
lords and serfs, who, having no work and means of subsistence, voluntarily agreed to become serfs of the nobility for their benefit. However, even in such circumstances, people retain freedom of belief and religion, but not the right to resist the government (Kormych, 2009, p. 85-86). At the same time, the state is the main guarantor of human security (Demydenko, Petryshyn, 2009, p. 107-108).

Gottfried Wilhelm (von) Leibniz (1646-1716) developed the concept of natural law and advocated the unity of the German states. He combined reason and faith, the ideas of the lawbound state and the police state, democracy, and absolutism. According to the thinker, the state arises as a result of a social contract, and the subject of power is the state itself, but not the person of the ruler (Moshkovskaya, 1965, p. 531), so, there, if desired, we can see the echo of the doctrine of Jean Bodin on the state sovereignty...

Christian Thomasius (1655-1728) developed the political and legal science free from theology, but he believed that natural law was granted by God, at the same time, the state arises as to the result of the social contract, but not God's providence. According to the thinker, people are ambitious and selfish, which prevents them from living in peaceful communication among themselves (Kormych, 2009, p. 86-88). Morality is similar to the advice of a teacher and is provided by persuasion, while the law is the instruction of the ruler, which is provided by coercion (Demydenko, Petryshyn, 2009, p. 108). For wise people, advice is enough, while for fools, coercion is necessary, so the government saves people from fear of the harm that fools can cause. The state, according to Thomasius, arises as a result of two social contracts - the agreement on unification into the state and the agreement on the appointment of the ruler. The main aim of power is to preserve peace in society, and the best and greatest form of government is the monarchy. The precondition for the monarch's power is the consent of the people, so the last one has no right to resort to violence and resist the first one. At the same time, the government should not encroach on the freedom of thought, beliefs, religion, and personal life of citizens (Kormych, 2009, p. 86-88).

Christian Freiherr von Wolff (1679-1754) substantiated the ideas of enlightened absolutism, the police state, and etatism with the help of the concept of natural law. According to the thinker, in the "natural conditions", people lived in families but did not have sufficient means to improve themselves and their life. The families decided to unite in the state to achieve common well-being, security, and improvement. The people handed over their supreme power to the government, so with the formation of the state, the people themselves restricted their freedom. In the same way, everyone has the right to restrict his freedom and to give himself into slavery, whence, appears the division of people into masters and serfs. The best form of government is the monarchy. The laws of the state are the practical implementation of the natural law, which gives the freedom, necessary to perform duties; at the same time, the limits of this freedom are determined by the power of the state, the power of the educated monarch, who cares for the common welfare and regulates all spheres of human activity. To ensure the general welfare, the monarch should have unlimited power in matters of war and peace, legislation, justice, the appointment of officials. The monarch should be virtuous, love his people, know the science of public administration, and have wise advisers, not act arbitrarily. People must unconditionally obey their monarch because the resistance to the state power threatens society to return to its "natural conditions" with all its imperfection and threats (Kormych, 2009, p. 8890).

Thus, it should be noted that, in general, German thinkers of the Baroque era - Samuel Freiherr von Pufendorf (1632-1694), Gottfried Wilhelm (von) Leibniz (1646-1716), Christian Thomasius (16551728), Christian Freiherr von Wolff (1679-1754) with the help of ideas of natural law and social contract legitimized and rationalized the existing monarchies, promoted the cult of the state and the law and order introduced by it (Demydenko, Petryshyn, 2009, p. 107-109; Kormych, 2009, p. 84-90), substantiated the princely and educated absolutism, the police state, etatism, serfdom, etc.

Also, it should be borne in mind that German pedantry, the desire for order, and conservative ideas were further reflected in the works of the philosophers of the German Historical School of Jurisprudence - Gustav Hugo (1764-1844), Friedrich Carl von Savigny (1779-1861), Georg Friedrich Puchta (1798-1846), - who, criticizing 
ideas of natural law and social contract, defended the monarchy, feudalism, serfdom, customary law, denied the codification of law, separation of powers and the right of the people to rebellion (Kormych, 2009, p. 138-142), i.e. creatively developed and continued the anti-liberal ideas of Samuel Freiherr von Pufendorf (1632-1694), Gottfried Wilhelm (von) Leibniz (1646-1716), Christian Thomasius (1655-1728), Christian Freiherr von Wolff (1679-1754).

\section{CONCLUSIONS}

Thus, summarizing the above, we have made the following conclusions:

1. Theories of natural law and social contract were and remain the leading political and legal doctrines.

2. The theory of natural law and social contract, in essence, is much wider and substantial than the usual political and legal doctrine, and it is a kind of meta concept, or, more precisely, an approach to the understanding of state and legal phenomena.

3. The contractual and natural-legal approach to the understanding of the state and law allows to reveal their nature in all its diversity and multifacetedness and to substantiate opposed, both liberal and conservative, views on the essence of political and legal phenomena.

4. Nowadays, the most popular version of the theory of natural law and social contract is the teachings of J. Locke and J.J. Rousseau, who believed that the state arises as to the result of the social contract, and the people, as the party of this agreement, have equal rights with the government and even have the right to revolt and terminate the social contract if the government violates the treaty or rules tyrannically. This interpretation of the ideas of natural law and the social contract laid the foundations of liberalism, democracy, human rights, the rule of law, constitutional and lawbound states, civil society, and so on.

5. However, the liberal version of the natural law doctrine and contractual theory of the origin of the state is quite dangerous for the state and society, because it justifies the people's right of rebellion as well as the right to terminate the social contract for petty reasons, and this is the great threat to the stable development and legality. At the same time, we should not forget that the theory of natural law and social contract very clearly indicates that the main purpose of the state power is to ensure the common welfare, so rulers should not be perceived as executioners and satraps, and the state - as a suppressor of freedom and enemy of human rights.

6. In our opinion, the conservative interpretation of the ideas of natural law and social contract, presented in the doctrines of Thomas Hobbes, Edmund Burke, Samuel Freiherr von Pufendorf, Gottfried Wilhelm (von) Leibniz, Christian Thomasius, Christian Freiherr von Wolff, in the best way reveals the essence of political and legal phenomena and the nature of state and law.

Following these thinkers, it should be said that the pre-state period was characterized by chaos (which could be somewhat balanced due to the small population density, which, to some extent, reduced the frequency of clashes, but excluded the possibility of systematic development of society, as it is sometimes observed in our time in so-called "natural communities", such as the American Indians).

The absence of the state and law during the period of the "natural conditions" led to the lack of the difference between legal and illegal, lawful and lawless. At that time dominated the animal orders of the wild world, based on natural selection, interspecific and intraspecific competition. The absence of the "unity and struggle of opposites" excluded the possibility of dialectical development. At some moment, ancient people understood the necessity of unity to ensure the achievement of the common welfare, but the "social contract", probably, was not concluded at once by the formal bureaucratic procedure. The social contract, probably, was concluded spontaneously and in the form of the implicative actions, when the subjects simply agreed with (did not resist) the establishment of a certain power over them, which, on the one hand, restricted their natural freedom and, on the other hand, provided them with certain support and protection. Thus, the state arises as to the triad of classical attributes - the people, territory, and power.

The creation of the states by different peoples was connected with the family kinship, territorial factors, economical and production necessity of some contacts, also, with the internal (the class divide and domination of rich people over the poor) 
and external (the conquest of the one tribe by another one) violence, which is the factual basis of the power and governing.

Thus, the social contract is not a historical event, but it is the political and legal concept, which is the basis of statehood. The concept of the social contract determines the main principles of the relations between the people and the ruler and says that people should bow to the rule of the state and the state should provide the people's interests and necessities. At the same time, the theory of the social contract, in any way, does not contradict but may be organically combined with the patriarchal and class-materialist theory of the origin of the state, as well as with the theory of violence.

We must agree with the opinion that when the state was created, the people renounced their natural freedom in exchange for care, assistance, and protection, provided by the state. It shows the inequality of the parties of the social contract, so the people are not the sovereign, but they are only the inhomogeneous group of liegemen. At the same time, one of the duties of the state is to protect people one from another with the help of the enforcement and punishments, based on the justice and the natural law, embodied in the positive law. It is necessary to say that the state power, as an arbiter in private conflicts and a governing force, must stand over the people, because otherwise the fundamental principle of justice "no one can be a judge in his case" will be violated, and, in general, the governance will be impossible, because the relations of subordination may not exist between the equal subjects.

The so-called "right of rebellion" was the ideological instrument in the era of the

\section{WORKS CITED}

Bobrovnyk, S.V. (2003). The natural law // The legal encyclopedia: in 6 vol. / ed. prof. Yu.S. Shemshuchenko and others. Kyiv: Publishing house M.P. Bazhan "Ukrainian encyclopedia". Vol. 5. https://leksika.com.ua/18990927/legal/prirodne_pravo

Burke, E. (1790). Reflections on the revolution in France, and on the proceedings in certain societies in London relative to that event. In a Letter Intended to Have Been Sent to a Gentleman in Paris. London: Printed for James Dodsley, in Pall-Mall.

Demydenko, G.G., Petryshyn, O.V. (2009). History of legal and political studies. Kharkiv: Law, 256 p.

Hobbes, T. (1651). Leviathan or The Matter, Forme and Power of a Commonwealth Ecclesiasticall and Civil. London: Printed for Andrew Crooke.

Kormych, A.I. (2009). History of legal and political studies. Kyiv: Legal unity. 312 p. bourgeoisie's struggle against the feudal system. In our time, especially under the conditions of the republican form of government, the periodic change of government with the help of the regular elections provides an opportunity to correct existing shortcomings without destroying the institution of statehood.

Thus, the right of rebellion has completely exhausted itself as an absurd idea, which suggests the possibility to break the social contract for petty reasons and destroying statehood. So, the right of rebellion threatens the society with much greater troubles than the troubles, which led to the uprising.

The correct understanding of the natural law (as the law of nature) and of the social contract (as the fundamental grounds for the subordination of the people to the ruler of the state, which should ensure the achievement of the common welfare) allows us not only to substantiate the cult of the state and law but also to disclose the useful etatistic and paternalistic essence of the state, the violent nature of the governance and the coercive nature of law, which are necessary to ensure the common welfare based on the reason, God, nature, and justice.

It is necessary to say that the conservative interpretation of the political and legal phenomena, made on the grounds of the natural law and the social contract by the certain English (Thomas Hobbes, Edmund Burke) and German (Samuel Freiherr von Pufendorf, Gottfried Wilhelm (von) Leibniz, Christian Thomasius, Christian Freiherr von Wolff) philosophers of the XVII - XVIII centuries, was continued by the thinkers of the next epochs and remains relevant to this day. 
Kukhta, B. (2003). The Leviathan // Political science. Dictionary: categories, concepts, and terms / edited by B. Kukhta. Lviv: Calvary. p. 218-219.

Locke, J. (1690). Two Treatises of Government: In the Former, The False Principles, and Foundation of Sir Robert Filmer, and His Followers, Are Detected and Overthrown. The Latter Is an Essay Concerning The True Original, Extent, and End of Civil Government. London: Printed for Awnsham Churchill, at the Black Swan in Ave-Mary-Lane, by Amen-Corner.

Moshkovskaya, Yu.Ya. (1965). Leibniz // The Soviet historical encyclopedia: in 16 vol. / Ch. ed. Ye.M. Zhukov. Moscow: The Soviet encyclopedia. Vol. 8. p. 530-532.

Novgorodtsev, P. (1898). The natural law // The Brockhaus and Efron Encyclopedic Dictionary. Vol. XXIV-A. Saint Petersburg. Typo-lithography of I.A. Efron. p. 885-890.

Romanyuk, A. (2003). The social contract // Political science. Dictionary: categories, concepts, and terms / edited by B. Kukhta. Lviv: Calvary. p. 132.

Rousseau, J.J. (1762). Du contrat social; ou, Principes du droit politique. Amsterdam: Éditeur MarcMichel Rey.

Tymoshenko, V.I. (1998). The contractual theory of the origin of state // The legal encyclopedia: in 6 vol. / ed. prof. Yu.S. Shemshuchenko and others. Kyiv: Publishing house M.P. Bazhan "Ukrainian encyclopedia". Vol. 2.

https://leksika.com.ua/17190303/legal/dogovirna_teoriya_pohodzhennya_derzhavi

Received for publication: $\quad 16.06 .2021$

Revision received: $\quad$ 24.06.2021

Accepted for publication: $\quad$ 06.07.2021

\section{How to cite this article?}

Style - APA Sixth Edition:

Kononenko, Y. S., \& Dzholos, S. V. (2021, July 15). Natural law and social contract: Conservative philosophers' view (XVII - XVIII centuries). (Z. Cekerevac, Ed.) MEST Journal, 9(2), 28-34. doi:10.12709/mest.09.09.02.05

Style - Chicago Sixteenth Edition:

Kononenko, Yurii S., and Sergii V. Dzholos. 2021. "Natural law and social contract: Conservative philosophers' view (XVII - XVIII centuries)." Edited by Zoran Cekerevac. MEST Journal (MESTE) 9 (2): 28-34. doi:10.12709/mest.09.09.02.05.

Style - GOST Name Sort:

Kononenko Yurii S. and Dzholos Sergii V. Natural law and social contract: Conservative philosophers' view (XVII - XVIII centuries) [Journal] // MEST Journal / ed. Cekerevac Zoran. - Belgrade - Toronto : MESTE, July 15, 2021. - 2 : Vol. 9. - pp. 28-34.

Style - Harvard Anglia:

Kononenko, Y. S. \& Dzholos, S. V., 2021. Natural law and social contract: Conservative philosophers' view (XVII - XVIII centuries). MEST Journal, 15 July, 9(2), pp. 28-34.

Style - ISO 690 Numerical Reference:

Natural law and social contract: Conservative philosophers' view (XVII - XVIII centuries). Kononenko, Yurii S. and Dzholos, Sergii V. [ed.] Zoran Cekerevac. 2, Belgrade - Toronto : MESTE, July 15, 2021, MEST Journal, Vol. 9, pp. 28-34. 